\title{
Reconstitution of Oxidative Phosphorylation in Submitochondrial Particles by a Soluble Protein Phosphoryl Transferase ${ }^{1}$
}

\author{
ROBERT E. BEYER ${ }^{2}$
}

\begin{abstract}
Institute for Enzyme Research, University of Wisconsin, Madison, Wisconsin 59706, and the Laboratory of Chemical Biology, Department of Zoology, The Lniversily of Michigan, Ann Arbor, Michigan 48104
\end{abstract}

Received June 5, 1967; accepted July 10, 1907

\begin{abstract}
A protein designated phosphoryl transferase has been isolated from beef heart mitochondria and has been found to increase the ability of submitochondrial particles, oxidizing either NADH or suceinate, to synthesize ATP from ADP and inorganic orthophosphate. Increases in the value of $\mathrm{P}: \mathrm{O}$ ratios between 0.45 and 1 have been ubserved with succinate as substrate. Phosphoryl trausferase was released from beef heart mitochondria by sonic disruption in the presence of EDTA and was then purified by fractionation with anmonium sulfate, chromatography on DEAE-cellulose, and recycling inolecular sieve chromalugraphy on poly acrylamide gel (BioGel P-200). The isolated phosphoryl transferase displayed a single peak in the analytical ultra(entrifuge and a single band in strip electrophoresis. Its molecular weight was estimated to be 124,000 ; its isoelectric point, pH 5.7. The absorption spectrum of the protein showed a maximum at $278-280 \mathrm{~m} \mu$, a minimum at $250 \mathrm{~m} \mu$, and a shoulder at $290 \mathrm{~m} \mu$. At $\mathrm{pH} 13$ two distinct maxima appeared at $282 \mathrm{~m} \mu$ and $288.5 \mathrm{~m} \mu$. Increases in the P:O ratios of submitochondrial particles, induced by purified phosphoryl transferase, were observed only at the site of energy conservation between reduced coenzyme $Q$ and cytochrome $c$. The protein has also been isolated from phosphorylating submitochondrial particles. During recycling gel filtration, a protein was separated from the phosphoryl transferase which inhibited the ATPase activity of submitochondrial particles and comteracted the effect of the phosphoryl transferase in inereasing the $\mathrm{P}:($ ) ratio.
\end{abstract}

Although the phenomenon of ATP synthesis supported by electron transfer has been known since $1939(1,2)$, knowledge is

1 This research was supported in part by $\mathrm{Na}$ tional Institutes of Health Grants AM $06751 \mathrm{MET}$ and AM $10056 \mathrm{BIO}$ from the National Institute of Arthritis and Metabolic Diseases; Institutional (irant 94 (The University of Michigan) from the National Science Foundation: American Cancer Society Institutional Grant (The University of Michigan) IN-40G; and Institutional Research Grant 94 to The University of Michigan from the American Cancer Society. Meat by-products were generously fumished by Oscar Mayer and Co., Madison, Wisconsin.

2 The major part of this research was performed while the anthor was the recipient of a Research Career Development Award [5-K3-GM-4862] from the National Institute of General Medical Science. scant concerning either the mechanism of oxidative phosphorylation or the identity of the catalytic components. One approach to this problem is by way of dissecting the mitochondrial system into component parts and reconstituting oxidative phosphorylation from these relatively purified components. This approach has led to the isolation and study of a class of proteins from various sources generally known as "coupling factors," 3 which are considered to be

"The term "coupling factor" has been used to describe protein preparations which, when included in the assay of the phosphorylative capacity of submitochondrial particles, enhance the efficiency of oxidative phosphorylation. The term implies that the protein factor is operating on, or influencing directly, the coupling process. Since 
component catalytic units required for the terminal step of oxidative phosphorylation (3-25) and of photosynthetic phosphorylation (26-28). In the present communication the isolation and properties of one such protein factor, phosphoryl transferase, are described, together with its effect on beef heart submitochondrial particles of low phosphorylative capacity. Some of these data have been reported in preliminary communications $(16,17)$.

\section{EXPERIMENTAL PROCEDURES}

Preparation of parlicles. Unless otherwise stated, all steps in the preparation of the assay particle, ETPH(EDTA-2) ${ }^{4}$ and of phosphoryl transferase were carried out at $0-4^{\circ}$. Heavy beef heart mitochondria were prepared according to the large scale procedure of Crane et al. (30), except that the "light-heavy" split was accomplished at $\mathrm{pH} 7.8 \mathrm{in}$ a medium which was $0.25 \mathrm{~m}$ in sucrose, and $0.01 \mathrm{~m}$ in Tris-HCl (sucrose-Tris) according to Hatefi and Lester (31). The procedure employed for the preparation of ETPH(EDTA-2) was essentially that of Limnane and Titchener (7) as described by Beyer (32). The Spinco model I. ultracentrifuge was used for all ecntrifugations. HBHM were suspended at a concentration of 10 $\mathrm{mg}$ of $\mathrm{protein} / \mathrm{ml}$ in a solution which was $0.25 \mathrm{~m}$ in

the coupling between energy-releasing and energy-conserving reactions of the mitochondrion is generally considered to occur at the level of the electron transfer chain, and since evidence has not been provided in favor of "coupling factors" interacting directly with electron transfer components, the term "coupling factor" would appear to be premature and inappropriate in this context. Such proteins, however, do appear to be involved in the sequence of reactions leading to the synthesis of ATP. The term "phosphoryl transferase" describes a known enzymic capability of the factor we have isolated, and as such carries no implication as to exactly how and where it is operative.

${ }^{4}$ Abbreviations used: ETPH(EDTA-2), electron transfer particle prepared from heavy beef heart mitochondria in the presence of EDTA, the numeral 2 referring to the second, and longer, procedure as described in (32); EDTA, ethylenediaminetetraacetic acid; Tris, tris(hydroxymethyl)aminomethane; DFAF, diethylaminoethane; PMS, phenazine methosulfate; 2,4-I)NP, 2,4-dinitrophenol; $\quad F_{3} C C P$, paratrifluoromethoxycarbonylcyanide phenylhydrazone; $\mathrm{CoQ}_{1}$, coenzyme $Q_{1}$ (ubiquinone-1); HBHM, heavy beef heart mitochondria. sucrose, $0.01 \mathrm{~m}$ in Tris- $\mathrm{HCl}, \mathrm{pH} 7.5$, and $1 \mathrm{~mm}$ in EDTA, and were sedimented at 17,000 rpm for 10 minutes. The pellet was suspended in sucroseTris, $\mathrm{pH} 7.6$, at a concentration of $20 \mathrm{mg}$ of protein $/ \mathrm{ml}$, stored at $-20^{\circ}$ for one week, and exposed to at least 5 freeze-thaw cycles. Immediately prior to sonic treatment, the suspension was made 2 mu in ELTA and adjusted to $\mathrm{pH} 7.5$; it was then irradiated with $20 \mathrm{kc}$ sound in a Branson sonifier (Branson Ultrasonics Corporation, model LS75) at 7-8 A for 60 seconds. The suspension was irradiated in a jacketed beaker, around which was circulated ethyleneglyool at $-10^{\circ}$. The temperature of the suspension did not rise above $6^{\circ}$ during sonic treatment. The $\mathrm{pH}$ was subsequently adjusted to 7.5 and the preparation was centrifuged at $20,000 \mathrm{rpm}$ for 10 minutes. The supernatant suspension was centrifuged at $50,000 \mathrm{rpm}$ for 30 minutes and the pellet was suspended in sucrose-Tris-EDTA (1 mu) medium, $\mathrm{pH} 7.5$, the final volume being half the original volume before sedimentation. The suspension was then sedimented again at 50,000 rpm for 30 minutes. Suspension and sedimentation were repeated twice in sucrose-Tris, $\mathrm{pH} 7.5$, and the final pellet was suspended in the same medium for immediate use, or in the preserving mixture of Limnane and Titchener (7), in $0.5-\mathrm{ml}$ aliqutots for storage at $-20^{\circ}$.

Assay procedure. Oxidative phosphorylation was assayed manometrically at $30^{\circ}$ as described in detail by Beyer (32). The assay system was $0.25 \mathrm{M}$ in sucrose, $0.033 \mathrm{M}$ in glucose, $6.6 \mathrm{~mm}$ in $\mathrm{MgCl}_{2}$, $5.2 \mathrm{~mm}$ in $P_{i}$, and $1.67 \mathrm{~mm}$ in ATP, and contained $0.1 \mathrm{mg}$ of crystalline hexokinase, and $1 \mathrm{mg}$ of ETPH(EDTA-2) in a final volume of $3 \mathrm{ml}$. When NADH was used as substrate it was generated in a system containing $0.5 \mu$ mole of NAD, $0.3 \mathrm{mg}$ of crystalline yeast ethanol dehydrogenase $(100 \mathrm{U})$, $60 \mu$ moles of ethanol, and $90 \mu$ moles of semicarbazide in a final volume of $3 \mathrm{ml}$. Succinate was used at an initial concentration of $6.67 \mathrm{~mm}$. When reduced cytochrome $c$ served as substrate, the system contained $10 \mu$ moles of ascorbate, $3 \mathrm{~m} \mu$ moles PMS, and $2 \mu \mathrm{g}$ of antimycin $A$. The Warburg vessels were kept on shaved ice until they were placed in the water bath. Fractions to be assayed were added last and reactions were initiated, following a 5-minute warm up period, by the addition of oxidizable substrate from a side arm. All assays were terminated after 20 minutes by the addition of $2 \mathrm{ml}$ of $1.5 \mathrm{M}$ perchloric acid. $\mathrm{P}_{\mathrm{i}}$ was measured by the isobutanol-benzene extraction method of Martin and Doty (33) as described by Lindberg and Ernster (34), the restlts being corrected for controls carried out in the absence of substrate and at zero time.

I'reparation of phosphoryl transferase

(35). 
HBHM were suspended at a concentration of 30 mg of protein/ml in a solution which was $0.15 \mathrm{~m}$ in $\mathrm{KCl}, 0.01 \mathrm{w}$ in Tris- $\mathrm{HCl}, \mathrm{pH} 7.5$, and $5 \mathrm{~mm}$ in HDTA. A volume of $40 \mathrm{ml}$ was treated with $20 \mathrm{kc}$ sound at $7-8$ A for 60 seconds. In a typical preparaion, 12-15 $\mathrm{gm}$ of HBHX protein were used as starting material. The suspension was adjusted to pH 7.5 with $\mathrm{KOH}$ and centrifuged a. $30,000 \mathrm{r} \mathrm{pm}$ for 90 minutes. The superuatant fluid (stage $\mathrm{A}$ ) was removed carefully, and was then treated with solid ammonium sulfate to $45 \%$ saturation at $0^{\circ}$ $(25.6 \mathrm{gm} / 100 \mathrm{ml})$; the mixture was stored at $-2^{\circ}$ overnight. The suspension was clarified by centrifugation at $15,000 \mathrm{rpm}$ for 10 minutes, and the clear, yellow-red supernatant solution was adjusted to 70 ; saturation with solid ammonium sulfate $(15.6 \mathrm{gm} / 100 \mathrm{ml})$. After 30 minutes the precipitate was collected by centrifugation and dissolved in a minimal volume of $0.05 \mathrm{~m}$ pot assium bicarbonate previously adjusted 10 $\mathrm{pH} 7.5$ with $\mathrm{HCl}$. This stage in the purification will be referred to as stage $B$. The stage $B$ preparation was dialyzed for 4-6 hours against 4 liters of $5 \mathrm{~mm}$ Trissulfate, pH 7.5, with one change of dialysis fluid midway through dialysis. The small flocenlent precipitate was removed by centrifugation. JWAE-substituted cellulose was prepared for chromatography by removal of fine particles in distilled water. The cellulose was washed successively with $1 \times \mathrm{HCl}$, water, $1 \times \mathrm{NaOH}$, water, 1 $\mathrm{N} \mathrm{HCl}$, water, and $1 \mathrm{~m}$ Tris-sulfate until the $\mathrm{pH}$ of the suspension reached 7.5 . The cellulose, thus treated, was stored in the Tris-sulfate solution until ready for use. As noted by Himmelhoch and Peterson (36), DEAE-substituted celluloses from various manufacturers may differ in their properties. The most consistent resolution was obtained with BioRad Cellex-I) (obtained from the Calilornia Corporation for Biochemical Research, Tos Angeles, California). Columns of IDEAE-cellulose $(20 \times 220 \mathrm{~mm})$ were prepared and washed with approximately $100 \mathrm{ml}$ of $5 \mathrm{~mm}$ Tris-sulfate, $\mathrm{pH}$ 7.5. Up to $1 \mathrm{gm}$ of the dialyzed and freeze-dried stage $B$ fraction, dissolved in $50 \mathrm{~mm}$ Tris-sulfate, $\mathrm{pH} 7.5$, was passed through a column $(40 \times 450$ mm) of sephadex ( $-25 \mathrm{M}$, previously equilibrated with $5 \mathrm{~mm}$ Tris-sulfate, pH 7.5. The lyophilized product was stable for several months when maintained at $-20^{\circ}$. The Sephadex eluate was applied to the 1)EAE-cellulose column and the columm was washed with 5 mm Tris-sulfate, $\mathrm{pH} 7.5$, until the absorbancy of the elftuent ( $1 \mathrm{~cm}$ path) at 278 $m \mu$ was below 0.1 . A linear gradient containing Tris-sulfate at eoncentrations varying between 0.005 and $0.15 \mathrm{M}, \mathrm{pH} 7.5$, was applied to the col$11 \mathrm{mn}$. The mixing ehamber and the reservoir each contained $300 \mathrm{ml}$ of solution. Phosphoryl transferase was eluted when the concentration of Tris- sulfate was approximately $80 \mathrm{~mm}$. The fraction at this stage of purification was designated stage $C$.

Further purification was achieved by multieycle chromatography on a molecular sieve ool$11 \mathrm{~mm}$ in the LKB ReCyChrom apparatus according to the techniques described by Porath and Bennich (37). Several lyophilized preparations at stage $\mathrm{C}$ were pooled, equilibrated with $50 \mathrm{~mm}$ Tris-sulfate, $\mathrm{pH} 7.5$, on a Sephadex (i-25M column, and applied to a $40 \times 800-\mathrm{mm}$ column of the polyacrylamide gel" P-200 previously equilibrated with the same buffer. The column was maintained be1 ween $2^{\circ}$ and $4^{\circ}$ with a cooling jacket. The slage $\mathrm{C}$ preparation was applied to the bottom of the column and the developing solvent was pumped in the same direction. Since pressure colunteracted the gravity factor, compression was kept to it minimum and a good flow rate was maintained. Three passes of the stage C preparation through the column, corresponding to a total bed height of 2.4 meters, were sufficient to resolve stage $\mathrm{C}$ into two diserete fractions. The fraction corresponding to the major, slower moving peak induced increases in the P:O ratio of the test particle and was designated phosphoryl transferase, stage $D$. This protein fraction was stable for several weeks when stored at $-20^{\circ}$, or for a period of several months when stored at $-196^{\circ}$ in $50 \mathrm{~mm}$ Tris-sulfate, pH 7.5.

Electrophoretic mobility on cellulose polyacetate strips (Sepraphore III) was measured in a Gelman strip electrophoresis apparatus. Protein was determined by a biuret method (38), crystalline bovine serum albumin being used as standard. The concentrations of protein in dilute solutions of the phosphoryl transferase were determined spectrophotometrically; when the absorbansy at $279 \mathrm{~m} \mu(1 \mathrm{~cm}$ ) was multiplied by 1.1 (see Fig. 4) the product had the dimensions of $\mathrm{mg}$ protein $/ \mathrm{ml}$.

Wthanol dehydrogenase and hexokinase were obtained from Worthington Biochemical Corp., and oligomycin and antimycin $\mathrm{A}$ from the Wiscon$\sin$ Alumni Research Foundation. All ot her chemicals were of analytical reagent or equivalent grade. Molecular weight measurements were made by Ehrenberg's (39) method of approach to sedimentation equilibrium.

\section{RESULTS}

Purification of phosphoryl transferase. Table I contains data pertaining to the purification of phosphoryl transferase. Relative or absolute units of activity of the enzyme have not been calculated at the various stages of purification because an

"Biogel P-200, California Corporation for Biochemical Research, Los Angeles, Califormia. 
TABLE I

Purification of Phosphoryl Transferase

\begin{tabular}{l|c|c|c|c}
\hline $\begin{array}{c}\text { Stage of } \\
\text { purification }\end{array}$ & $\begin{array}{c}\text { Volume } \\
(\mathrm{ml})\end{array}$ & $\begin{array}{c}\text { Protein } \\
(\mathrm{mg})\end{array}$ & $\begin{array}{c}\text { Protein re- } \\
\text { quired for } \\
\text { saturation }^{a} \\
(\mu \mathrm{g} / \mathrm{mg})\end{array}$ & $\Delta \mathbf{r}: \mathrm{O}^{j}$ \\
\hline HBHM & 246 & 9470 & & \\
$\mathrm{~A}$ & 396 & 1410 & & \\
$\mathrm{~B}$ & 19 & 362 & 2000 & +0.18 \\
$\mathrm{C}$ & $4^{c}$ & 10.2 & 60 & $+\mathbf{0 . 2 6}$ \\
$\mathrm{D}$ & $4^{c}$ & 6.4 & 28 & $+\mathbf{0 . 6 4}$ \\
\hline
\end{tabular}

a The amount of phosphoryl transferase in $\mu \mathrm{g}$ protein required to induce a maximal increase in the $\mathrm{P}: \mathrm{O}$ ratio of ETPH(EDTA-2).

${ }^{b}$ Difference between the $\mathrm{P}: O$ ratio obtained in the presence and absence of phosphoryl transferase in saturating amounts. The $\mathrm{P}: O$ ratio was determined in the presence of succinate as substrate; the control $\mathrm{P}$ : O ratio was 0.19 .

c The protein was determined after concentration by lyophilization.

inhibitor appears to be present which is not removed until the final purification step is performed. An indication of degree of purification obtained at each step may be ascertained from the data on the amount of phosphoryl transferase required to obtain maximal stimulation of oxidative phosphorylation $(\Delta \mathrm{P}: \mathrm{O})$. In the particular preparation represented in Table I, $28 \mu \mathrm{g}$ of phosphoryl transferase at stage $D$ sufficed to saturate $1 \mathrm{mg}$ of ETPH(EDTA-2), whereas $60 \mu \mathrm{g}$ of the fraction at the previous stage in the purification (stage $\mathrm{C}$ ) was required to saturate the same amount of particle. On the basis of saturation data, the purification would be slightly over twofold. This would appear unlikely, however, in view of the fact that over $60 \%$ of the protein applied to the P-200 column was recovered. Moreover, some of the protein cluted from the P-200 column was lost during concentration and subsequent solubilization. It is also noteworthy that the amount of phosphoryl transferase at stage $\mathrm{C}$ required to saturate 1 $\mathrm{mg}$ of particle is more than twice that required for the preparation at stage $\mathrm{D}$. The final step in the purification apparently separates the phosphoryl transferase from an inhibitory substance.

Figure 1 shows a typical pattern of the data obtained by gradient elution when the
stage-B fraction was chromatographed on DEAE-substituted cellulose. Every third fraction was assayed for activity in increasing the $\mathrm{P}^{\mathrm{P}}: \mathrm{O}$ ratio of ETPH(EDTA-2) under the assay conditions described in ExPERImental Procenures with succinate as substrate. Each fraction was tested whenever activity was demonstrable in an area of elution. In fractions 90-98 (Fig. 1), eluted by approximately $80 \mathrm{~mm}$ Tris-sulfate, activity was demonstrable. Active fractions were pooled and are referred to as stage-C phosphoryl transferase.

Stage $\mathrm{C}$ was purified further by chromatography involving ReCyChrom gel filtration (37) as described above and previously (35). Figure 2 illustrates a typical separation pattern of several combined preparations of phosphoryl transferase at stage C. Two distinct peaks were observed and bled from the column. Protein in the larger, slower moving peak increased the $\mathrm{P}: \mathrm{O}$ ratio of FTPH(FDTA-2). The faster moving, minor component, on the other hand, was found to counteract the increase in P:O ratio induced by phosphoryl transferase. Details of this phenomenon are presented below. In the experiment depicted in Fig. 2 some diffusion of the peaks appears to have occurred as indicated by the spread of the peaks. This was not a consistent observation; the extent appeared to depend upon the packing and previous use of the column. Recovery of protein was usually between 65 and $80 \%$ of that applied to the ReCyChrom column. In one experiment, for example, $124 \mathrm{mg}$ of phosphoryl transferase at stage $\mathrm{C}$ was applied and $7 \mathrm{mg}$ of the fast-moving and 78 $\mathrm{mg}$ of the major peak were recovered. Among other parameters, recovery greatly depended upon where the bleeding valve was opened to remove protein from the column. In these experiments the valve was not opened to remove protein from the ReCyChrom column until the recorder showed a value of $95 \%$ transmission. This practice ensured a minimum of crosscontamination of protein tailing from the first into the second peak, but it also lowered the recovery.

Physical properties of phosphoryl transferase. The sedimentation characteristics of phosphoryl transferase at the $\mathrm{C}$ and $\mathrm{D}$ stages 


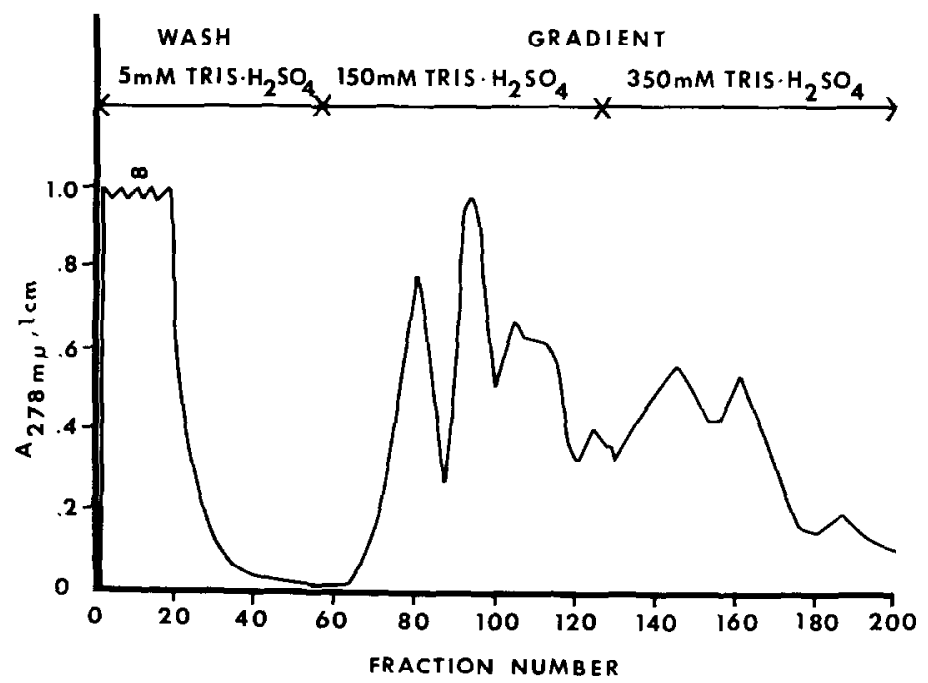

Fig. 1. Gradient elution chromatography of a preparation of phosphoryl transferase at stage $B$ of purification on DEAE-substituted cellulose. A fresh preparation of fraction $B$ (200 mg of protein) was applied to a column of Sephadex $G-25 \mathrm{M}$ equilibrated with $5 \mathrm{~mm}$ Trissulfate, pH 7.5. The eluant was applied to a $20 \times 220-\mathrm{mm}$ column of DEAE-cellulose which had been equilibrated with $5 \mathrm{~mm}$ Tris-sulfate, $\mathrm{pH}$ 7.5. The loaded column was washed with approximately $200 \mathrm{ml}$ of $5 \mathrm{~mm}$ Tris-sulfate, $\mathrm{pH} 7.5$. Fractions of $3.5 \mathrm{ml}$ each (64 drops) were collected when protein began to be eluted from the column. The column was developed at an approximate rate of $50 \mathrm{ml} /$ hour. A linear gradient system was started (where indicated) by using two $500-\mathrm{ml}$ chambers, the mixer chamber containing $300 \mathrm{ml}$ of $5 \mathrm{~mm}$ T'ris-sulfate and the reservoir chamber containing an equal volume of $150 \mathrm{mu}$ Tris-sulfate. Where indicated, the nixer chamber was filled to $300 \mathrm{ml}$ with $150 \mathrm{~mm}$ Tris-sulfate and a new gradient was started by using $300 \mathrm{ml}$ of $350 \mathrm{~mm}$ Tris-sulfate in the reservoir chamber.

of purity have been observed in the Beckman model $\mathrm{E}$ analytical ultracentrifuge. Figure 3 contains pictures of the course of sedimentation of the protein at stage C (Fig. $3 \mathrm{~A}$ ) and at stage $\mathrm{D}$ in the purification (Fig. 3B). At stage $\mathrm{C}$, phosphoryl transferase contained two visible components, a minor faster moving component with an $s_{20, w}$ value of $\$ .95$ and a major slower moving component with an $s_{20, w}$ of $6 \mathrm{~S}$. After gel filtration on BioGel P-200 (Fig. 3B) the phosphoryl transferase appeared to be homogeneous and sedimented with an $s_{20, w}$ value of 6.1. This value corresponds to that of the major component of the preparation at stage C. From the data for the approach to sedimentation equilibrium at the meniscus for seven periods during the run, a mean molecular weight of 124,000 was computed.

The activity of phosphoryl transferase was destroyed by exposure to $65^{\circ}$ for 2 minutes. The protein was nondialyzable and, in addition, was eluted from Sephadex
G-25M with an $R_{F}$ of 1 . The absorption spectrum of phosphoryl transferase in the ultraviolet region is typical of many protcins (Fig. 4). Since the shoulder at $290 \mathrm{~m} \mu$ suggested the presence of ionizable tyrosine groups, the protein was treated with alkali to observe the nature of the $290 \mathrm{~m} \mu$ contribution. The spectrum after addition of $\mathrm{KOH}$ to a final $\mathrm{pH}>13$ showed a new minimum at $269 \mathrm{~m} \mu$, a loss of absorptivity at $27 \mathrm{~s} \mathrm{~m} \mu$, and two distinct peaks at 282 and $288.5 \mathrm{~m} \mu$, respectively. The difference spectrum between the spectra of the enzyme at $\mathrm{pH}$ values 13 and 7.5 revealed a trough at $274 \mathrm{~m} \mu$ and a peak at $295 \mathrm{~m} \mu$.

Figure 5 shows diagrammatically the direction of electrophoretic migration of the enzyme at three $\mathrm{pH}$ values. The protein migrated toward the cathode at $\mathrm{pH}$ 4.5 $(I=0.05)$. The protein remained at the point of application when the $\mathrm{pH}$ of the medium was 5.7. Only one band was noted on strips to which the enzyme at stage D 


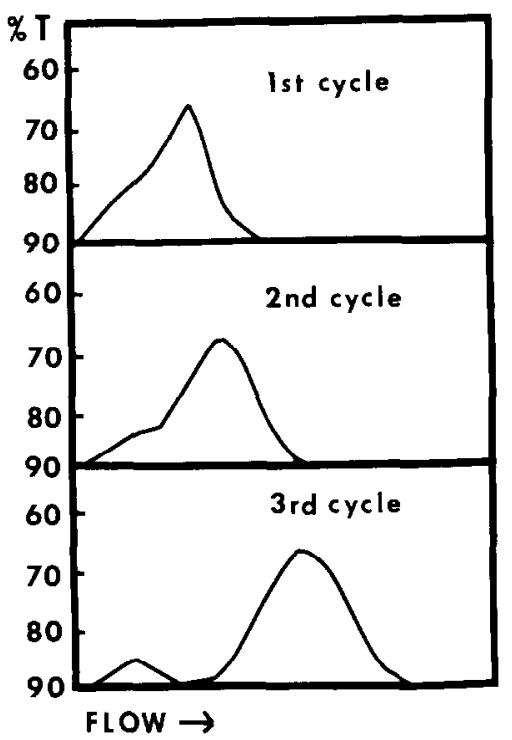

FiG. 2. Chromatography of phosphoryl transferase, stage $\mathrm{C}$, on BioGel in the ReCyChrom apparatus. Six ml of a solution containing $80.4 \mathrm{mg}$ of phosphoryl transferase protein at stage $C$ was applied to a BioGel P-200 column previously equilibrated with degassed $50 \mathrm{~mm}$ Tris-sulfate, $\mathrm{pH}$ 7.5. The rate of flow was $28 \mathrm{ml} /$ hour. Each cycle required approximately 16-18 hours. Elution (from left to right) indicated that the minor peak traveled faster than the major peak, which contained the phosphoryl transferase.

was applied and electrophoresed at various $\mathrm{pH}$ values between 4 and 8 . However, when preparations of the transferase at the $\mathrm{C}$ stage of purification were examined at $\mathrm{pH}$ $4 . \overline{5}$, a minor component was found near the origin. The electrophoretic mobility of the minor component has not been studied in detail.

Phosphoryl transferase and oxidative phosphorylation. Table III shows the increment in the value of $\mathrm{P}: \mathrm{O}$ induced by the purified transferase under various conditions that define the site of energy conservation affected by the protein. It is interesting to note that at no stage in the preparation did the addition of the active fraction increase the phosphorylative capacity of ETPH (EDTA-2) at the third phosphorylation site. The adequacy of the assay system we have used for measuring ATP synthesis at the terminal site of oxidative phosphorylation has been documented previously (32) for submitochondrial particles capable of phosphorylation at the third phosphorylation site. The P:O ratios of the unsupplemented test particle with $\mathrm{NADH}$ as substrate ranged from 0.3 to 0.7 depending on the preparation used. l'hosphoryl transferase at stage B increased the P:O ratio oblaining with either NADH or succinate as substrate, the increase with $\mathrm{NADH}$ being about twice as large as that with succinate. Although this difference between the two substrates was not uniform, it was observed in about $80 \%$ of the experiments. The enzyme fraction, after purification on DEAE-substituted cellulose (stage $\mathrm{C}$ ), increased the P:O ratio in the presence of succinate to a greater extent than did the fraction at stage B. However, no such difference was observed between the two fractions with respect to the increase in P:O induced in the presence of $\mathrm{NADH}$ as substrate. After the phosphoryl transferase was further purified on BioGel P-200 the protein induced the same increase in P:O ratios whether succinate or NADH were used as substrate and the increase in $P: O$ per milligram of transferase protein was greater than theory on the basis of protein purification. As stated above, only some $10 \%$ of contaminating protein was eliminated by this process. The curves of Fig. 6 , showing the saturation of phosphoryl transferase with respect to the test particle, indicate that the enzyme thus purified was three times as active, and the total increase in $\mathrm{P}: \mathrm{O}$ induced by the preparation at stage-D purilication was substantially higher than that induced by the enzyme at the earlier stage of purification.

Esterification of $\mathrm{P}_{i}$ in the presence of the transferase was inhibited by oligomycin, 2,4-DNP, and $\mathrm{F}_{3} \mathrm{CCP}$; the respiration was inhibited by antimycin A. Bovine serum albumin, which has been shown to counteract the effect of uncouplers of oxidative phosphorylation (40), did not increase significantly the $\mathrm{P}: \mathrm{O}$ ratio of the test submitochondrial particle.

The apparent loss of the ahility to stimulate phosphorylation at the site of energy conservation between $\mathrm{NADH}$ and coenzy me $Q$ consequent on the further purification of the stage- $B$ fraction was examined 

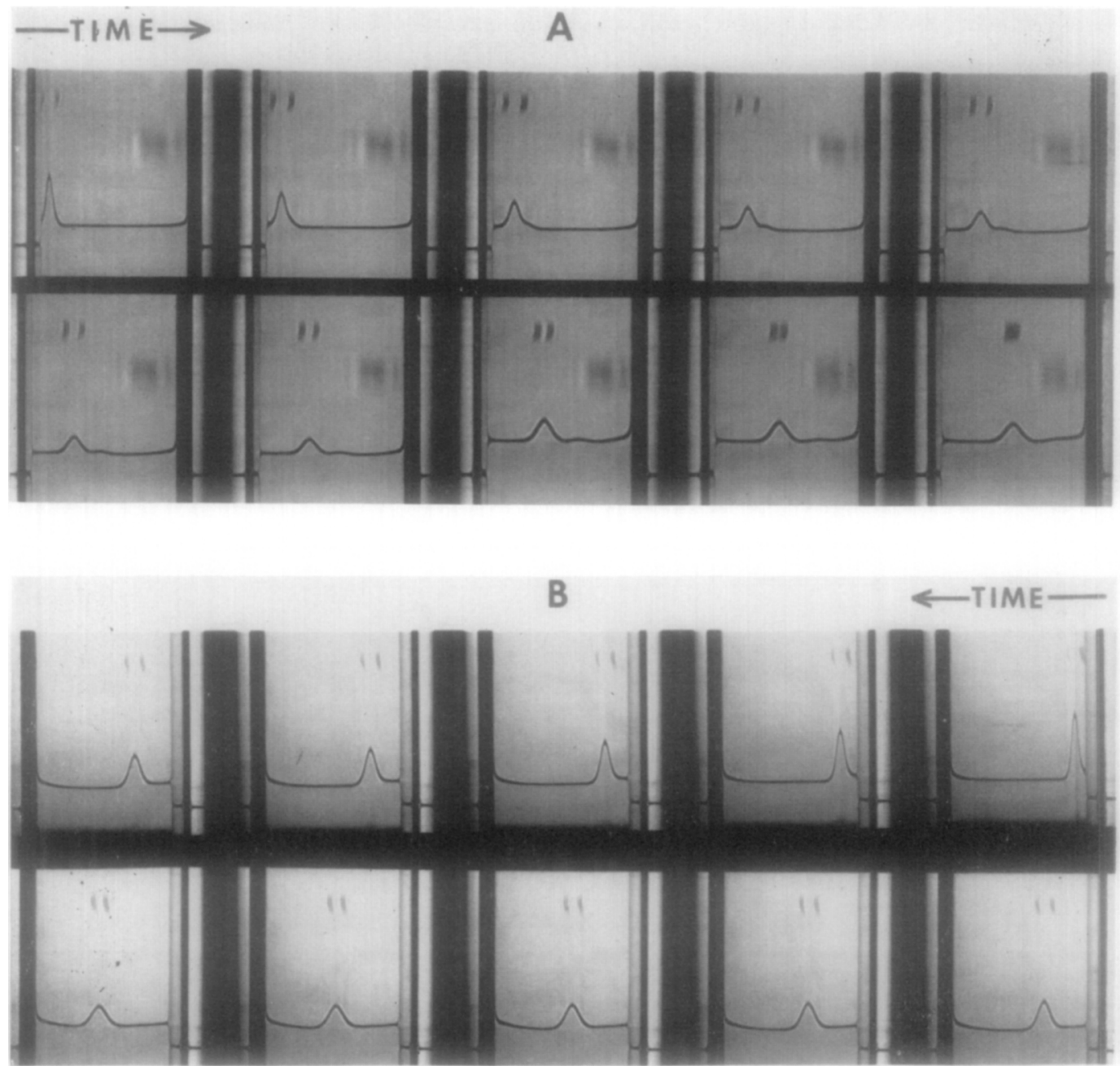

Fuc. 3. Analytical ultracentrifugation of phosphoryl transferase. Figure 3A (read from lef1 10 right) represents stage $C$ of a preparation containing $5.1 \mathrm{mg}$ of protein $/ \mathrm{ml}$. Figure $3 \mathrm{~B}$ (read from right to left) represents stage $\mathrm{D}$ of a preparation containing $6.8 \mathrm{mg}$ of protein/ml. The conditions were as follows: the medium, $0.1 \mathrm{~m}$ Tris-sulfate, $\mathrm{pH} 7.5$; temperaunre, $8.3^{\circ}$; speed, 59,780 rpm; piculure inlerval, 8 minules.

further in the assay system of Schatz and Racker (41), which is specific for site I. In confirmation of Schatz and Racker, "P:Q" ratios lying between 0.6 and 0.7 have been observed for the oxidation of $\mathrm{NADH}$ by coenzyme $Q_{1}$ catalyzed by $\operatorname{ETPH}\left(\mathrm{Mg}^{++}\right.$, $\left.\mathrm{M} \mathrm{n}^{++}\right)$(Table $\left.\mathrm{V}\right)$. The P:O ratio of the same preparation for the oxidation of $\mathrm{NADH}$ by molecular oxygen was 2.33. $\mathrm{F}_{3} \mathrm{CCP}$ abolished the esterification of $\mathrm{P}_{\mathrm{i}}$ coupled to the oxidation of $\mathrm{XADH}$ by coenzyme $\mathrm{Q}_{1}$. The $\mathrm{B}$ friction of the phosphoryl transferase preparation increased the $\mathrm{P}: \mathrm{Q}$ ratio in the assay system of Schatz and Racker, but the purified enzyme (at the $\mathrm{C}$ or D stage of purity) was not active in this respect.

Isolation of phosphoryl transferase from ETPH $\left(M g^{++}, M / n^{++}\right)$. To provide information on the localization of phosphoryl transferase in the mitochondrion, the isolation procedure was applied to the preparation of the transferase from $\operatorname{ETPH}\left(\mathrm{Mg}^{++}\right.$, $\left.\mathrm{M} \mathrm{n}^{++}\right)$. A number of large batches of this type of ETPH were prepared over a period 
TABLE II

Molecular weight of Phosphoryl transferase Computed from Data for the Approach to Sedimentation Equilibricm

\begin{tabular}{cr}
\hline Time (minutes) & $\mathrm{MW} \times 10^{5}$ \\
\hline 97 & 1.27 \\
113 & 1.26 \\
129 & 1.20 \\
145 & 1.23 \\
161 & 1.29 \\
177 & 1.25 \\
193 & 1.16 \\
& - Mean 1.24 \\
\hline
\end{tabular}

of several weeks and stored at $-20^{\circ}$. ETPH in the amount of $14.63 \mathrm{gm}$ was used as the starting material for the preparation. The procedure followed was identical with that for the preparation of the transferase from HBHM. The soluble supernatant fraction obtained after the centrifugation of the sonic-treated suspension (stage A) contained $419 \mathrm{mg}$ of protein, equivalent to $2.86 \%$ of the starting material. The peak eluted from DFAE-substituted cellulose contained approximately $23 \mathrm{mg}$ of protein or about $0.16 \%$ of the initial ETPH protein. This vield was somewhat higher than the $0.1 \%$ average yield of phosphoryl transferase from HBH.

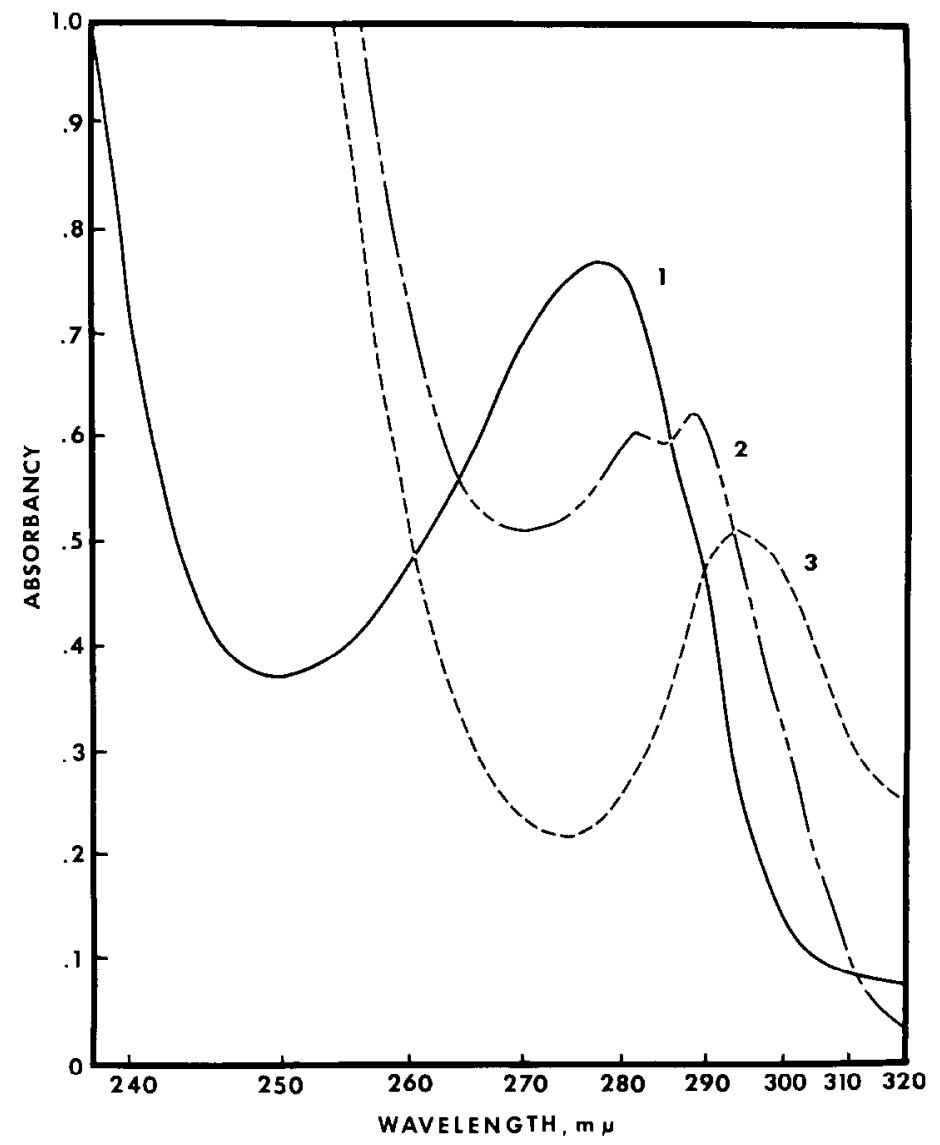

Fig. 4. Spectral shift of phosphoryl transferase (stage D) at high $\mathrm{pH}$. Spectra were recorded in a Beckman DK-2 spectrophotometer, path length, $1 \mathrm{~cm}$. A solution of Tris-sulfate $(0.7 \mathrm{ml}$ of $50 \mathrm{~mm}, \mathrm{pH} 7.5)$, containing $0.71 \mathrm{mg}$ of protein $/ \mathrm{ml}$ was placed in a $1-\mathrm{ml}$ cuvette, and the direct spert rum was recorded (-). Alkali $(0.1 \mathrm{ml}$ of $6 \mathrm{~N} \mathrm{KOH})$ was added and the direct. spectrum was recorded once more (- - - ). The difference spectrum (alkaline spectrum minus the spectrum at $\mathrm{pH}$ 7.5) was normalized to allow for differences in protein concentration (- - ). 


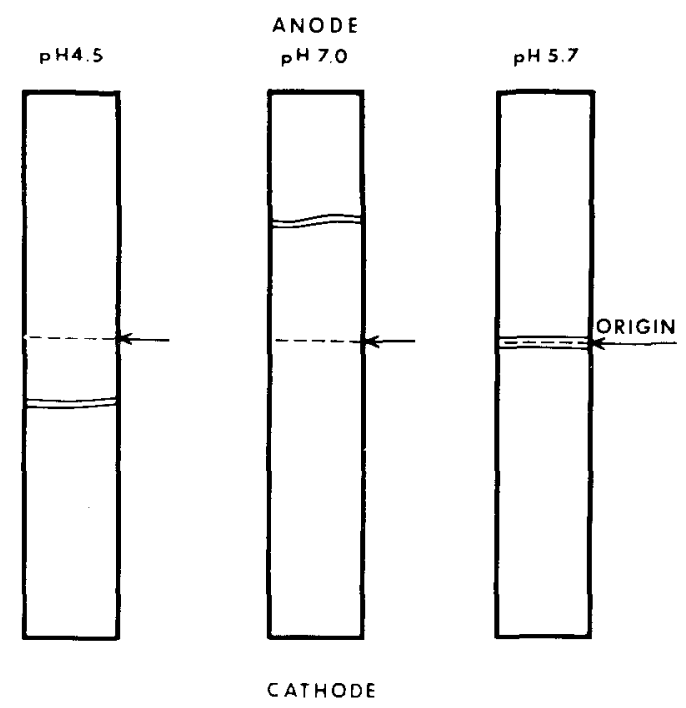

Frci. 5. Flectrophoretic mobility of phosphoryl 1 ransferase (stage I)). Mobility was measured in a (ielman strip) electrophoresis apparatus at $2^{\circ}, 190 \mathrm{~V}(11.7 \mathrm{~V} / \mathrm{cm})$ on Seprephore III cellulose polyacetate strips $(2.4 \times 16.3 \mathrm{~cm})$ in butfers of ionic strength (I) 0.05 . Approximately $0.05 \mathrm{ml}$ of a solution eontaining between 3 and $5 \mathrm{mg}$ of protein/ ml was applied to the strip with a (ielman applirator. The time of the runs was either 4 or 8 hours. Caffeine was used to correct for endosmosis. The strips were fixed and stained with $0.5 \%$ Ponceau $\$$ in $5 \%$ trichloroacetic acid and washed in $5 \%$ acetic arid. The buffer for the run at $\mathrm{pH} 4.5$ was acetic acid-sodium acetate, and the time was 4 hours. The buffers for the rums at $\mathrm{pH} 7$ and 5.7, respectively, were appropriate mixtures of cacodylic acid and sodium racodylate. The time of the elec1 rophoresis was 8 hours.

The purified transferase isolated from ETPH $\mathrm{Mg}^{++}, \mathrm{Mn}^{++}$) improved the $\mathrm{P}: \mathrm{O}$ ratio of ETPH(EDTA-2) with succinate as substrate, despite the fact that the test particles showed a relatively high residual phosphorylating capacity (Table VI). However, the particles from which the transferase had been extracted during its preparation from ETPH( $\left.\mathrm{Mg}^{++}, \mathrm{Mn}^{++}\right)$wore not stimulated with respect to coupled phosphorylation by the addition of the transferase. The rates of phosphorylation and of oxidation of succinate were both increased to approximately equal extents by the addition of transferase. Hence, the $\mathrm{P}: 0$ ratio remained unchanged.

Effect of inhibitor on ATPase and P:O.
The phosphoryl transferase after elution from the Biociel P'-200 column was more active per milligram of protein than eould have been expected on the basis of the proportion of inactive protein removed. Apparently, the faster moving component which was removed by gel filtration counteracted the enhancing effect of the transterase on the P:O ratio. We were led to this interpretation by the demonstration by Pullman and Monroy (42) of a factor in beef heart mitochondria which inhibits the ATPase activity of $\mathrm{F}_{1}$ the $\mathrm{ATP}$ alse isolated from beef heart mitochondria by Pullman ct al. (s)]. We tested the effect of the fanter moving protein fraction on the ATlise activity catalyzed by $\mathrm{ETPH}\left(\mathrm{Mg}_{\mathrm{g}}^{++}, \mathrm{X}_{\mathrm{n}^{++}}\right)$ and found it to be inhibitory (lig. 7 ). Inhibition was directly proportional to the concentration of the inhibitor protein up to 10 $\mu \mathrm{g} / \mathrm{ml}$, the maximal inhibition attained being $91 \%$ of that of the control activity. A greater extent of inhibition of the particle catalyzed A'TPase activity was not observed in any of the several experiments if this type which were performed.

The inhibitor fruction also interfered with the capacity of the transferase 10 increase the P:O ratio of ETPH(EI)TA-2) (Table VII). Two other observations are of interest. The inhibitor protein saturated the phosphorylating system at lower concentrations than those required for the maximal effect of phosphoryl transferase. Even at saturating levels of the inhibitor some enhancement of the $P: O$ ratio indued by the transferase was demonstrable. This would suggest competition between the inhibitor and the transferase for the same site, and also would argue against the possibility of the inhibitor acting as an uncoupler of oxidative phosphorylation. The fact that the inhibitor protein did not increase the state-4 respiration of intact HBHM with pyruvate as substrate may be interpreted as additional evidence that the inhibitor is not an uncoupler. The inhibitor protein also did not significantly effect the respiratory control ratio of HBHМ, which was routinely between 4 and 6. However, the lack of effect of the inhibitor protein on intact beef heart, mitochondria may be due to a lack of per 
TABLE III

InCreise in P':O INdUCed by Phosphoryl Transterase

Substrates were placed in the side arm of Warburg flasks, and all other components in the main compartment. The substrate was tipped into the main compartment; after 5 minutes of thermal equilibration oxygen consumption was measured for 30 minutes. All other conditions and concentrations of assay components were those described in the text.

\begin{tabular}{|c|c|c|c|c|c|c|}
\hline \multirow{2}{*}{ Substrate } & \multicolumn{2}{|c|}{ Transferase added } & \multirow{2}{*}{$\begin{array}{c}\text { Oxygen uptake } \\
\text { (mpatoms } / \text { mg } \\
\left.\text { prot. } .^{\prime 2} / \mathrm{min}\right)\end{array}$} & \multirow{2}{*}{$\begin{array}{c}P_{i} \text { uptake } \\
(\text { m } \mu \text { moles } / \mathrm{mg} \\
\left.\text { prot. }^{1 /} / \mathrm{min}\right)\end{array}$} & \multirow{2}{*}{$P: O$} & \multirow{2}{*}{$\Delta \mathrm{P}: \mathrm{O}$} \\
\hline & Stage & Amount (mg) & & & & \\
\hline \multirow[t]{4}{*}{$\mathrm{NADH}$} & - & $\ldots$ & 453 & 131 & 0.29 & - \\
\hline & $B$ & 1.72 & 424 & 233 & 0.55 & +.26 \\
\hline & $\mathrm{C}$ & 0.10 & 433 & 234 & 0.54 & +.25 \\
\hline & I) & 0.067 & 429 & 399 & 0.93 & +.64 \\
\hline \multirow[t]{4}{*}{ Succinate } & -- & - & 443 & 93 & 0.21 & - \\
\hline & $\mathrm{B}$ & 1.72 & 447 & 148 & 0.33 & +.12 \\
\hline & $\mathrm{C}$ & 0.10 & 439 & 197 & 0.45 & +.24 \\
\hline & I) & 0.067 & 455 & 377 & 0.83 & +.62 \\
\hline \multirow[t]{4}{*}{ Reduced cyt. $c$} & - & - & 139 & 13 & 0.09 & 一 \\
\hline & $\mathrm{B}$ & 1.72 & 155 & 8 & 0.05 & -.04 \\
\hline & $C$ & 0.10 & 146 & 12 & 0.08 & -.01 \\
\hline & D) & 0.067 & 132 & 12 & 0.08 & -.01 \\
\hline
\end{tabular}

a Refers to protein of ETPH(EDTA 2) only.

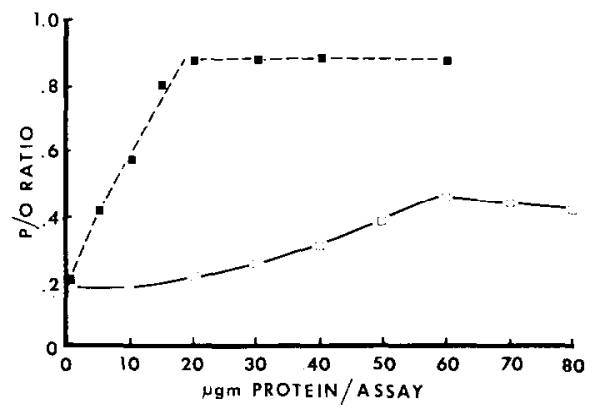

FIG. 6. Saturation of ETPH(EI)TA-2) with phosphory l lansferase respectively at stage C $(-)$ and stage $\mathrm{D})(--)$. The $\mathrm{P}: \mathrm{O}$ ratios were determined as described in the text. The units plotted on the abseissa are $\mu \mathrm{g}$ of transferase per assay, $1 \mathrm{mg}$ of ETPH(LITA-2) protein was present in each assay mixture. The duration of the experiment was 20 minutes. Succinate was used as substrate.

meability of the limiting mitochondrial membrane to the inhibitor protein.

\section{DISCUSSION}

A protein (phosphoryl transferase) has been isolated from beef heart mitochondria which appears to play a catalytic role in oxidative phosphorylation. The transferase increases the phosphorylative capacity of submitochondrial particles prepared under
TABLE IV

Response of Reconstituted System to ThCoUpling Agents and Inhibitors of Electrox ThaNsfer

Assays were performed as described in Table III and in the text. The substrate used was succinate. The concentrations used of the following additives were: $2,4-\mathrm{DNP}, 5 \times 10^{-5} \mathrm{~m} ; \mathrm{F}_{3} \mathrm{CCP}, 5 \times$ $10^{7} \mathrm{M}$; oligomycin, $1 \mu \mathrm{g} / \mathrm{mg}$ of protein; antimycin $\mathrm{A}, 0.4 \mu \mathrm{g} / \mathrm{mg}$ of protein.

\begin{tabular}{|c|c|c|c|c|}
\hline \multicolumn{2}{|c|}{ Additions } & \multirow{2}{*}{$\begin{array}{c}\text { Oz uptake } \\
\text { (mpatoms } \\
\text { mg prot. } \\
\text { min) }\end{array}$} & \multirow{2}{*}{$\begin{array}{l}\mathbf{P}_{\mathrm{i}} \text { uptake } \\
\text { (mpmoles } \\
\text { mg prot./ } \\
\text { min) }\end{array}$} & \multirow{2}{*}{$P: O$} \\
\hline $\begin{array}{l}\text { Trans- } \\
\text { ferase } \\
(\mu \mathrm{g})\end{array}$ & $\begin{array}{l}\text { Uncoupler or } \\
\text { inhibitor }\end{array}$ & & & \\
\hline- & $\cdots$ & 432 & 82 & 0.19 \\
\hline 40 & - & 446 & 343 & 0.77 \\
\hline 40 & $2,4-\mathrm{D} N \mathrm{P}^{3}$ & 441 & 4 & $<0.01$ \\
\hline 40 & $\mathrm{~F}_{3} \mathrm{CCP}$ & 433 & 3 & $<0.01$ \\
\hline 40 & Oligomycin & 427 & 8 & 0.02 \\
\hline 40 & Antimycin A & $<30$ & $<3$ & $<0.01$ \\
\hline \multicolumn{2}{|c|}{$\begin{array}{l}\text { Bovine serım albımin } \\
\quad(2 \mathrm{mg})\end{array}$} & 441 & 93 & 0.21 \\
\hline
\end{tabular}

specific conditions. The fact that the increase in P:O ratio induced by the transferase is abolished by uncouplers and inhibitors of oxidative phosphorylation and by inhibitors of the electron transfer process 


\section{TABLE $\mathrm{V}$}

Effect of Phosphoryl T'raxiferase on 'he P:Q Ratho of ETPII(EDTA-2)

Assays were performed as described by Schatz and Racker (40) at $30^{\circ}$ in a temperat ure-controlled Beckman DU-2 spectrophotometer in silica cuvettes with a 1-cm light path. The final concentrations of the components in $1 \mathrm{ml}$ were: $\mathrm{MgCl}_{2}, 2 \mathrm{~mm}$; EDTA, $0.48 \mathrm{~mm}$; Tris-sulfate, pH 7.4, $5 \mathrm{~mm}$; glucose, $32 \mathrm{~mm}$; ATI', $1 \mathrm{~mm}$; hexokinase, 10 units; crystalline bovine serum albumin, $2 \mathrm{mg}$; ${ }^{32} \mathrm{P}_{\mathrm{i}}, \mathrm{pH} 7.4\left(3.2 \times 10^{5} \mathrm{cpm} /\right.$ $\mu$ mole), $10 \mathrm{~mm}$; KCN (in $0.1 \mathrm{~m}$ Tris-sulfate, $\mathrm{pH} 7.4$ ), $1.6 \mathrm{~mm}$; CoQ $1,0.12 \mathrm{~mm}$; sucrose, $0.25 \mathrm{~s}$; LTPH protein, $200 \mu \mathrm{g}$. Reactions were initiated by the addition of $0.08 \mu$ mole of NADH with rapid stirring. The absorbancy was followed at $340 \mathrm{~m} \mu$ until the NAI)H was exhausted. ETPH $\left(\mathrm{Mg}^{++}, \mathrm{Mn}^{++}\right.$) was prepared as previously described $(32)$.

\begin{tabular}{|c|c|c|c|}
\hline Particle & Additions & $\begin{array}{l}\left(\mathrm{i}-6^{-{ }^{32}} \mathrm{P} \text { formed }\right. \\
(\mathrm{m} \mu \mathrm{moles})\end{array}$ & $\frac{\left(\mathrm{ll} u-0-\mathrm{P}^{\prime \prime}\right.}{\text { NADII }}$ \\
\hline $\operatorname{ETPH}\left(\mathrm{Mg}^{++}, \mathrm{Mn}^{++}\right)^{n}$ & -.. & 53 & $0.6 i c i$ \\
\hline ETPH $\left(\mathrm{Mg}^{++}, \mathrm{Mn}^{++}\right)$ & $\mathrm{F}_{3} \mathrm{CCP}, 5 \times 10^{-7} \mathrm{M}$ & 3 & $0.0 !$ \\
\hline \multirow[t]{4}{*}{ ETPII(EI)TA-2) } & -- & 14 & 0.18 \\
\hline & $1.5 \mathrm{mg}$ stage $-\mathrm{B}$ transf. & 27 & 0.34 \\
\hline & $0.10 \mathrm{mg}$ stage-C transf. & 12 & 0.15 \\
\hline & $0.06 \mathrm{mg}$ stage- $\mathrm{D}$ transf. & 15 & 0.19 \\
\hline
\end{tabular}

a The G-6-P:NADH ratio was considered to be equivalent to the P:O or P:Q ratio in the NADH-CoQ span. The value used for the $\mathrm{NADH}$ utilized was the amount of NADH added, $80 \mathrm{~m} \mu \mathrm{moles}$.

${ }^{6}$ The P:O ratio observed for this particulate preparation, with NADH as substrate and oxygen as oxidant, was 2.33

TABLE VI

Acjivity of Phosphoryi Transferase Isolated FRoM $\mathrm{ETPH}\left(\mathrm{Mg}^{++}, \mathrm{Mn}^{++}\right)$

Assays were performed as described in the text with succinate as substrate. $\operatorname{ETPH}\left(\mathrm{Me}^{++}\right.$, son.) refers to the particles recovered after sonic treatment of $\mathrm{ETPH}\left(\mathrm{Mg}^{++}, \mathrm{Mn}^{++}\right)$in the presence of a medium which was $0.15 \mathrm{M}$ in $\mathrm{KCl}, 5 \mathrm{~mm}$ in EDTA, and $0.01 \mathrm{~m}$ in Tris-chloride, $\mathrm{pH}$ 7.5. Each flask contained $1 \mathrm{mg}$ of particle protein in a total volume of $3 \mathrm{~m}$ ]. The experiment was terminated after 30 minutes.

\begin{tabular}{|c|c|c|c|c|}
\hline Assay particle & $\begin{array}{l}\text { Trans- } \\
\text { ferase } \\
\langle\mu g)\end{array}$ & $\begin{array}{l}\mathrm{P}_{\mathrm{i}} \text { uptake } \\
\text { (mumoles/ } \\
\text { mg prot. } \\
\text { min) }\end{array}$ & $P: O$ & $\Delta P: O$ \\
\hline \multirow[t]{2}{*}{ ЕТТ' (EDTA-2) } & 0 & 82 & 0.50 & $\ldots$ \\
\hline & 68 & 138 & 1.03 & +0.53 \\
\hline \multirow{2}{*}{$\begin{array}{l}\mathrm{ETPH}\left(\mathrm{Me}^{++}\right. \\
\text {son.) }\end{array}$} & 0 & 51 & 0.22 & $\longrightarrow$ \\
\hline & 68 & 89 & 0.28 & +0.06 \\
\hline
\end{tabular}

indicates that the effect is referable to the normal coupling mechanism. I'hosphoryl transferase has been isolated both from mitochondria and from submitochondrial particles capable of efficient oxidative phosphorylation. Thus it appears to be a component associated with the inner mitochondrial membrane, the membrane which contains the assembly of enzymes required to synthesize ATP (see 43).

The physical measurements of phosphoryl transferase not only provide biochemical data on the nature of the protein but also permit a comparison of this protein with a number of other factors reported to affect increases in phosphorylation. The molecular weight of phosphoryl transferase is approximately 124,000, whereas that of the ATP'ase $\left(\mathrm{F}_{1}\right)$ of Pullman et al. $(8,44)$ is reported to be 284,000. Additional differences between the two proteins have emerged from experiments (with Dr. (*. Schatz) which indicate that phosphoryl transferase is not capable of hydrolyzing ATP under conditions in which ATP is hydrolyzed by $\mathrm{F}_{1}$. In addition, the same experiments demonstrated that conditions which do not affect the ATPase activity of $\mathrm{F}_{1}\left(6.5^{\circ}, 2\right.$ minutes $)$ inactivate phosphoryl transferase. The transferase appears to differ in several respects from the factor isolated by Sanadi $e t$ al. $(10,15,18)$, despite the similarity of the procedures by which the two protcins are isolated. Sanadi's factor $\mathrm{A}$, like $\mathrm{I}_{1}$, shows cold-labile ATPase activity. However, the capability of sanadi's factor $A$ for improving the $\mathrm{P}: \mathrm{O}$ ratio of 


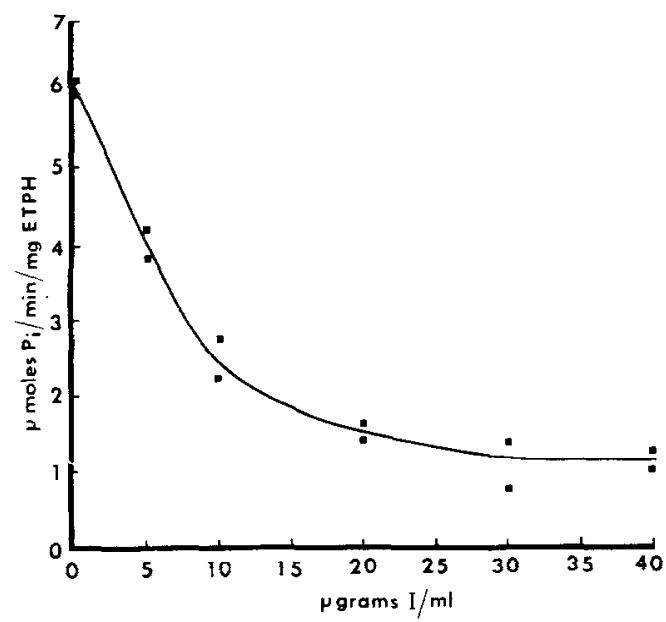

FIG. 7. The effect of inhibitor protein on the ATPase activity of ETPH $\left(\mathrm{Mg}^{++}, \mathrm{Mn}^{++}\right)$. Each assay tube, in a total volume of $1 \mathrm{ml}$, contained: $5 \mu$ moles of $\mathrm{MgCl}_{2}, 0.1 \mu$ mole of $2,4-\mathrm{DNP}, 0.1 \mathrm{mg}$ of particle protein, and $10 \mu$ moles of ATP. The reaction was initiated by the addition of ATP. The tubes were incubated for 10 minutes at $30^{\circ}$. The $P_{i}$ released from ATP was measured by the colorimetric method described by Lindberg and Ernster (34) and corrected for a control value in the absence of enzyme.

TABLE VII

Inhibition by Fraction I of the Enhancing Effect of Phosphoryl Transferase ON THE P:O RATIO

Snceinate was used as substrate; the duration of assay, 20 minutes; the temperature, $30^{\circ}$; the assay particle, ETPH(EDTA-2). Phosphoryl transferase at stage $C$ was chromatographed on BioGel P-200 in the ReCyChrom apparatis, and two distinct fractious were eluted. The faster moving, minor component is referred to as fraction $I$, and the slower moving, major component as phosphoryl transferase stage D. Other conditions and components were those described in the text.

\begin{tabular}{|c|c|c|c|c|}
\hline \multicolumn{2}{|c|}{ Additions } & \multirow{2}{*}{$\begin{array}{c}\mathrm{P}_{1} \text { uptake } \\
\text { ( } \mu \text { moles/ } \\
\text { assay) }\end{array}$} & \multirow[b]{2}{*}{$1: 0$} & \multirow[b]{2}{*}{$\Delta \mathbf{P}: 0$} \\
\hline $\begin{array}{c}\text { Transferase } \\
\text { at stage I) } \\
(\mu \mathrm{g})\end{array}$ & $\begin{array}{l}\text { Inhibitor } \\
\text { fraction I } \\
\text { (jy) }\end{array}$ & & & \\
\hline 一 & - & 1.40 & 0.17 & -- \\
\hline 50 & $\cdots$ & 6.94 & 0.81 & +0.64 \\
\hline 50 & 5 & 5.61 & 0.70 & +0.53 \\
\hline 50 & 10 & 3.02 & 0.38 & +0.21 \\
\hline 50 & 20 & 3.29 & 0.39 & +0.22 \\
\hline
\end{tabular}

treated particles is not cold-labile, and, unlike purified phosphoryl transferase, Sanadi's factor $\Lambda$ increases the rate of the $\mathrm{ATl}^{\mathrm{T}}$ energized reduction of NAD by succinate in extracted submitochondrial particles. Crude phosphoryl transferase, at stage B, stimulates reversed electron transfer catalyzed by ETPH(EDTA-2), but the ability to stimulate this reversal is lost on further purification of the transferase. It is interesting to note that fraction $c$ of I innane and Titchener (7) also increases the rate of ATPenergized reduction of $\mathrm{XAD}$ by succinate, catalyzed by ETPH(EDTA-2). Sonc and Hagihara (21) have reported the isolation of a factor which enhances $\mathrm{P}: 0$ ratios at phorphorylation sites 1 and 2 , but not at site 3 ; it shoms no detectable ATPase activity. This latter factor clearly differs from phosphoryl transferase in that its molecular weight is of the order of 200,000 or higher (excluded from Sephadex G-200), and it stimulates the $A T P$-driven reduction of NAD by succinate. Finally, phosphoryl transferase catalyzes an exchange between ATP and ADP' (45) and is phosphorylated during oxidative phosphorylation (46), two properties which clearly distinguish it from the several factors enumerated above. These two properties will be the subject of forthcoming manuscripts.

The appearance of a peak at $2950 \AA$ in proteins at $\mathrm{pH} 13$ is indicative of the emergence of ionized tyrosyl groups and is usually a token of protein denaturation (47, 48). Phosphoryl transferase shares this property with a group of proteins which includes ovalbumin, ribonuclease, lysozyme, insulin, and catalase (cf. 47 and 48).

The data presented herein, as well as those presented previously in preliminary form $(45,46)$, indicate that phosphoryl transferase is involved either in the transfer within the inner membrane of a phosphoryl group from some phosphoryl donor to $\Lambda \mathrm{Dl}^{\mathrm{P}}$, or in the teransfer of a phosphoryl group from internal ATP to external ADP. This interpretation is consistent with the findings that phosphoryl transferase catalyzes an exchange between $\Lambda \mathrm{TP}^{\mathrm{P}}$ and $\mathrm{ADI}$ (45), and that the enzyme forms a phosphorylated intermediate that can phos- 
phorylate ADP with formation of ATP (46).

\section{ACKNOWLEDGMENTS}

The anthor expresses his gratitude to Professor David E. Green for advice, encouragement, and laboratury facilities during the course of most of these investigations; to Dr. Pauline Yang for experiments performed with the analytical nltracentrifuge and for calculations of molecular weights; to MIr. Earl Fronk for skilled technical assistance; to Mr. Zul Jivani for the large scale preparation of crude enzyme; and to Miss Connelia Woermann and Dr. Alary Buell for aid in the preparation of the manuscript. Dr. Arthur $F$. Wagner of Merk, Nharp and Dohme Researeh Laboratories provided a generous gift of coenzyme $\left(Q_{1}\right.$, and 1$) \mathrm{r}$. P. G. Hevtler of E. I. du Pont de Nemonrs and Co. kindly supplied paratrifluoromethoxyearbonylcyandephenylhydrazone. I take especial pleasure in acknowledging the tor brief collaboration with Dr. Gontfried Schatz.

\section{REFETRENCES}

1. Belitzer, I. A., axo Tzibakova, E. T., BioRihimia 4, 510 (1939).

2. Kанокаг, H. MI, Enzymologia 6, 209 (1939).

3. Pixemot, (x. B., J. Biol. Chem. 205, 65 (1953).

4. Brome. A. F., ANm GraY, C. T., Biochim. Biophys. Lcta 19, 384 (1956).

5. Linixe, A. W., Biochim. Biophys. Acla 30, $221(1958)$.

6. Pleliman, M. L., Penefsery, H., and Racker, E., .1rch. Biochem. Biophys. 77, 227 (1958).

7. Liminate, A. W., axd Timghener, E. B., Biochim. Biophys. Acla 39, 469 (1960).

8. Plilmax, M. E., Penefskr, H. S., Datta, A., ixi Rathert, E., J. Biol. ('hem. 235, 3322 $\langle 1960)$.

9. Pexefok r, H. s., Puldata, M. F., Datta, A., AND Racker, E., J, Biol. Chem. 235, 3330 (1960).

10. Saxad, D. R., Flehatity, A. L., and Axpreol, T. L., Biochem. Biophys. Res. Commen. 8, 200 (1962)

11. Ishikawa, S., and Jehnivger, A. L., $J$. Biol. Chem. 237, $2401(1962)$.

12. Hownes, F. A., Biochim. Biophys. Acta 71, $595(1963)$.

13. Asaxo, A., And Bronte, A. F., Biochem. Biophys. Res. Commun. 13, 416 (19)(i3).

14. Covoveli, T. E., Pratrie, R. L., aNd Racker, E., r. Binl. Chem. 238, 2831 (19)(33).

15. Saxadi, D. R., and Fluharty, A. L., Biochemistry 2, 523 (1963).

16. Beyer, Ti. E., Federulion Proce. 23, 132 (1964).
17. Beyer, R. E., Biochem. Biophys. Res. Commun. 16, 460 (1964).

18. Andreoli, T. E., Lam, K.-W., and Sanabi, D. R., J. Biol. Chem. 240, 2644 (1965).

19. Ketrman, J., Biochem. Biophys. Res. Commun. 19, 237 (1965).

20. Ishikawa, s., $J$. Biochem. (Tokyo) 60, 598 (1966).

21. Sone, N., anil Hagihara, B., J. Biochem. ('Tokilyo) 60, 622 (1966).

22. Pandi-Hovenkamp, H. (i., Biochim. Biophys. Atcta 118, 645 (1966).

23. Fessexden, J. M., DanNenberg, M. A., and liacker, E., Biochem. Biophys. Res. Commun. 25, 54 (1966).

24. Fessexiden, J., and Rackele, H., J. Biol, Chem. 241, 2483 (1966).

25. Lam, K.-W., WalishaW, J. B., AND SANADI, D. R., Arch. Biochem. Biophys. 119, 477 (1967).

26. Krogman, D. W., axb M. L. Struler, Biochem. Biophys. Res. Commun. 7, 46 (1962).

27. Aveos, Mi., Biochim. Biophys. Acla 77, 6994 (196i3).

28. Vambetas, V. K., ano Racken, E., I. Biol. rhem. 240, 2660 (1965).

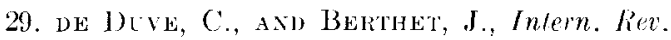
Cylol. 3, $225(1954)$.

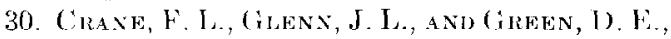
Biochim. Biophy... Acta 22, 455 (1956).

31. Haferir, Y., and Lester, R. L., Biochim. Biophys. Acta 27, 83 (1958).

32. Berer, R. E., in "Methods in Enzymology," Vol. 10 "'Oxidation and Phosphorylation"; R. W. listabrouk and M. L. Pullman, eds.), p. 186. Academic I'ress, New York (1967).

33. Matrin, J. B., Axid Dotr, D. M., Inal r'hem. 21, $965(1949)$

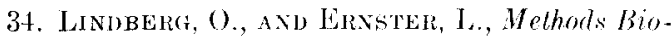
chem. Anal. 3, $1(1956)$.

35. BEYER, R. E., in "Methods in Enzymology," Vol. 10 "Oxidation and Phosphorylation"; R. W. Estabrook and M. E. Pullman, eds.), p. 519. Acaulemie Press, New York (1967).

36. Himmelhoci, S. R., And Peterson, E. A., Anal. Biochem. 17, 383 (1966).

37. Poliath, J., AхD Bexnich, H., tich. Biochem. Biophys., Suppl. 1, 152 (1962).

38. Golryali, A. G., Baminathe, C. J., and David, M. M., J. Biol. Chem. 177, 751 (1949).

39. Eimenbeiri, A., Acta Chem. Scand. 11, 125 (1957).

40. Weinbachl, L. C., and GakBt's, J., J. Biol Chem. 241, 169 (1966).

41. Si:hatz, G., and liacker, E., I. Biol. Chem. $241,1429(1966)$.

42. Plllman, M. E., and Mogror, G. C., J. Biol. Chem. 238, 3762 (19963). 
43. Green, D. E., ano Tzagoloff, A., Arch. Biochem. Biophys. 116, 293 (1966).

44. Racker, E., Plluman, M. F., Penefsky, H. S., and Silverman, M., Proc. $V$ Intern. Congr. Biochem. 5th, Moscow, 1961 Vol. V (E. C. Slater, ed.), p. 303. Pergamon Press, Oxford (1963).
45. Beyer, R. E., Biochem. Biophys. Res. Commun. 17, 764 (1964).

46. Beyer, R. E., Biochem. Biophys. Res. Commun. 17, 184 (1964).

47. Wetlaufer, D. B., Advan. Protein Chem. 17, 303 (1962).

48. Tanford, C., Advan. Protein Chem. 17, 69 (1962). 